\title{
Effect of moderate dosage of chlorpropamide in pregnancy on fetal outcome
}

\author{
H. W. SUTHERLAND, P. D. BEWSHER, J. D. CORMACK,` C. R. T. HUGHES, \\ ANNE REID, G. RUSSELL, and J. M. STOWERS \\ From Aberdeen Maternity Hospital, Aberdeen
}

\begin{abstract}
Sutherland, H. W., Bewsher, P. D., Cormack, J. D., Hughes, C. R. T., Reid, A., Russell, G., and Stowers, J. M. (1974). Archives of Disease in Childhood, 49, 283. Effect of moderate dosage of chlorpropamide in pregnancy on fetal outcome. The outcome of 19 pregnancies is reviewed in women receiving daily doses of at least $200 \mathrm{mg}$ chlorpropamide for varying degrees of glucose intolerance. 4 required insulin in late pregnancy. In 13 mothers who had chlorpropamide during the first 13 weeks of pregnancy no fetal abnormality occurred. There were 2 intrauterine deaths, 1 neonatal death, 6 babies with birthweights greater than the 90th centile, and 2 with birthweights below the 10th centile. The total dosage taken during pregnancy varied from 5 to $105 \mathrm{~g}$ and the duration of administration varied from 3 to 39 weeks. Though the severity of diabetes loosely correlated with the daily chlorpropamide dosage, no constant relation existed between high daily dosage of chlorpropamide and obstetric or neonatal complications. It is concluded that it is more likely to be the poor control of the maternal diabetes in pregnancy than a pharmacological effect of the chlorpropamide on the fetal pancreas which is responsible for the poor results reported. 6 infants had intravenous glucose tolerance tests done within 3 hours of birth and the rate of glucose disposal and insulin response was found to be greater than in infants of untreated mothers with less severe diabetes.
\end{abstract}

Treatment of 'chemical' diabetes with chlorpropamide in a daily dosage of $100 \mathrm{mg}$ during pregnancy improves maternal intravenous glucose tolerance and has no adverse effect on the perinatal survival (Sutherland et al., 1973).

Although chlorpropamide is apparently a suitable form of therapy for this mild degree of diabetes, two reports have warned of increased fetal hazard (Campbell, 1963; Kemball et al., 1970), and it may be that the severity of diabetes or the dosage of chlorpropamide given (MacPhail, 1963) is responsible for this apparent discrepancy. It is well known that there is frequently a marked deterioration of glucose tolerance with advancing gestation, but this is by no means uniform and it is at least theoretically likely that a tablet form of therapy will produce less satisfactory control of a changing metabolic state than injection of insulin with the daily dosage regulated according to urine testing. Therefore, we

Received 1 October 1973.

*Present address: Oakville Trafalgar Memorial Hospital, Oakville, Ontario, Canada. considered it worth while reporting our total experience in the use of chlorpropamide in a dosage of $200 \mathrm{mg}$ or more daily during 19 pregnancies, 13 of which were in women whose diabetes was already controlled by chlorpropamide at conception.

The amount of chlorpropamide and duration of treatment are considered in relation to teratogenicity, perinatal mortality, infant birthweight, and neonatal progress; and glucose and insulin values after a glucose challenge are compared in the infants of 6 of the 19 mothers with the infants of 9 mothers with chemical diabetes who received no treatment during pregnancy.

\section{Patients and methods}

Of the 19 women reported in this study, 13 were already taking chlorpropamide at conception and 4 of those required insulin in late pregnancy to re-establish control of the diabetes. Of the 6 women started on chlorpropamide therapy during pregnancy, 4 were diagnosed by a $25 \mathrm{~g}$ rapid intravenous glucose tolerance test (IVGTT) and were found to have increment indices (Duncan, 1956) of $1.87,1 \cdot 73,1.38$, and $2 \cdot 39$, 
respectively (normal $>2.97$ ); the remaining 2 were found to have blood sugars of 144 and $172 \mathrm{mg} / 100 \mathrm{ml}$, respectively, 3 hours after food during pregnancy.

The mean age of the 19 women was $31 \cdot 5$ (range 25-40) years, mean parity 1.5 (range 1-5), mean calculated (Hytten and Leitch, 1971) pre-pregnancy weight $54.0 \mathrm{~kg}$ (range $41 \cdot 3-72 \cdot 1 \mathrm{~kg}$ ), and all social classes were represented evenly. The gestational ages of the infants varied from 30 weeks to 39 weeks with a mean of 37 weeks (Fig. 1). There were 12 spontaneous vertex deliveries, 5 caesarean sections, and 2 assisted breech deliveries.

Actual birthweights were allocated to centile categories by comparison with Aberdeen birthweight tables (Thomson, Billewicz, and Hytten, 1968) which take into account gestational age, sex of baby, maternal height, weight for height, parity, and social class.

The procedures used to study the effects of maternal chlorpropamide therapy on the newborn have been published recently (Sutherland et al., 1973). Whole blood glucose was estimated by a standard manual glucose oxidase method (Hugget and Nixon, 1957) and plasma immunoreactive insulin was estimated by the method of Hales and Randle (1963). In 3 infants of the chlorpropamide-treated mothers, blood glucose and plasma insulin were estimated in cord venous and arterial samples, and capillary blood glucose levels were estimated serially from birth to 90 minutes of life. Those babies and 3 others from the chlorpropamidetreated group had glucose and insulin levels measured five times after the injection of glucose $(0.5 \mathrm{~g} / \mathrm{kg}$ body weight) via an umbilical venous catheter. These results were compared with others obtained in the same way from the infants of 9 mothers with mild chemical diabetes (mean increment index $2 \cdot 4 \pm 0 \cdot 3 \mathrm{SD}$ ), who had not been treated due to late diagnosis.

An attempt was made to relate the condition, based on the clinical appearance and signs and biochemical criteria, of the newborn infants to (a) the control of maternal diabetes during pregnancy and (b) the total amount of chlorpropamide taken during pregnancy. The following definitions were used.

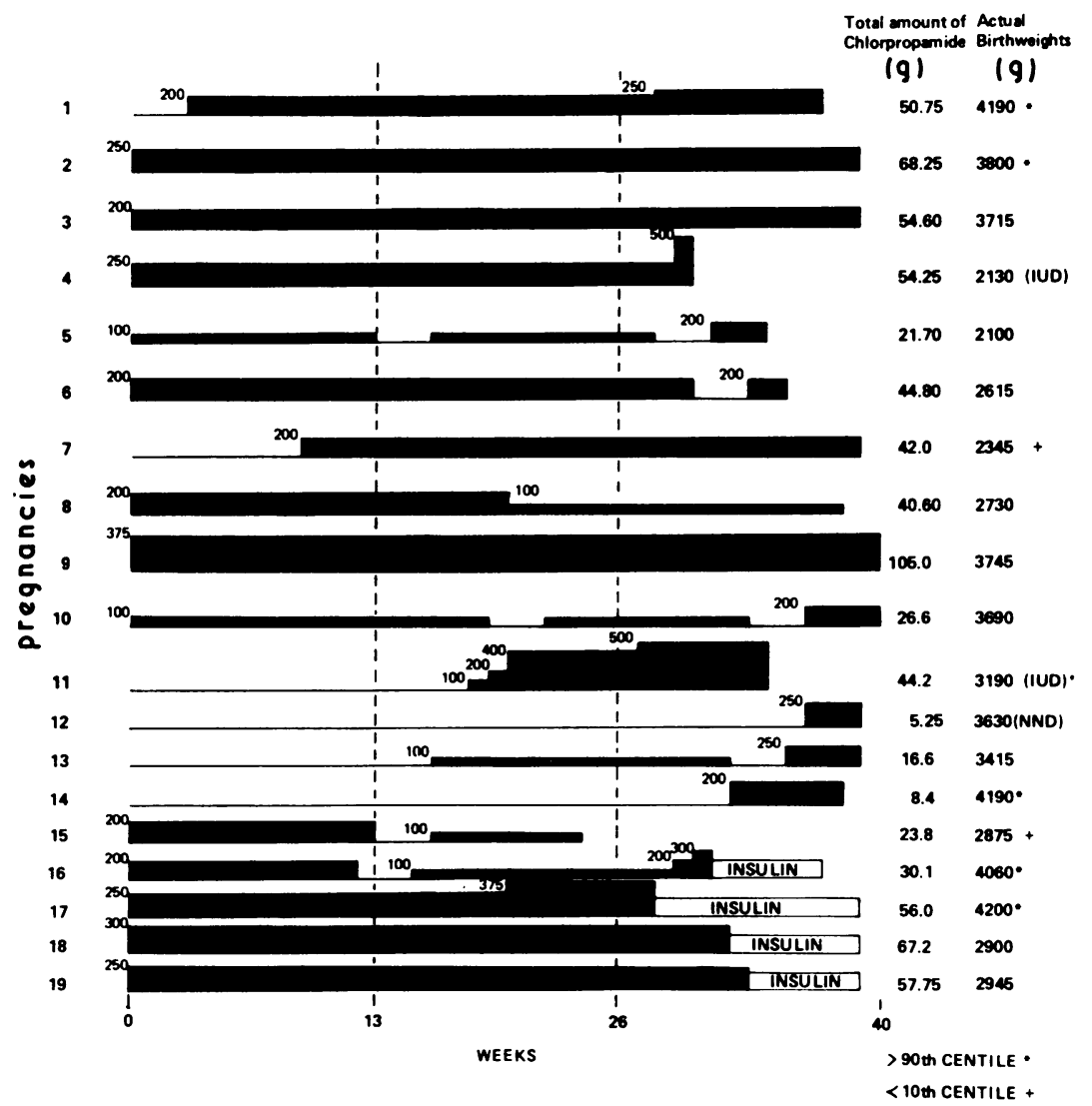

FIG. 1.-Pattern of chlorpropamide therapy in each individual during pregnancy, indicating total chlorpropamide dosage overall, actual birthweights of each infant with abnormal centile birthweights where relevant, and perinatal loss (IUD, intrauterine death; NND, neonatal death). 
Clinical appearance of infant. Typical: if infant large, plump, and plethoric with hairy ears, and described in notes as a typical IDM (infant of diabetic mother). Not typical: absence of above criteria.

Clinical signs. Positive: infants developed one or more of these signs-jitteriness, respiratory distress, and cyanotic or apnoeic attacks. Negative: infants developed none of these.

Criteria for biochemical abnormalities. Positive: infants had one or more of the followingblood glucose $25 \mathrm{mg} / 100 \mathrm{ml}$ or less, serum calcium 3.5 $\mathrm{mEq} / \mathrm{l}$. or less, or serum indirect bilirubin concentration $20.0 \mathrm{mg} / 100 \mathrm{ml}$ or more at any time.

Total dosage of chlorpropamide. This is the total amount in $g$ of the drug that the mother had taken throughout her pregnancy. Total doses of chlorpropamide below the mean $(43.04 \mathrm{~g})$ for all patients were defined as low and those above the mean as high This subdivision was justified by the statistically significant difference between the means of the doses of chlorpropamide in the two groups so defined.

Control of maternal diabetes. Good control was said to exist if at no time during the pregnancy maternal blood glucose concentration rose above $135 \mathrm{mg} / 100 \mathrm{ml}$ at an afternoon clinic visit. Bad control was said to exist if at any time or times during pregnancy maternal blood glucose concentration was above $170 \mathrm{mg} / 100 \mathrm{ml}$ at an afternoon clinic visit. These arbitrary standards were determined by the fact that no results lay between the two limits.

\section{Results}

Fig. 1 shows the amount and duration of chlorpropamide therapy during each of the 19 pregnancies reported, with the actual birthweights. Birthweights $<10$ th centile and $>90$ th centile category, 2 intrauterine deaths, and 1 neonatal death are also indicated. Cases 16-19 had treatment with insulin in late pregnancy because maternal postprandial blood sugar levels were judged to be too high when estimated during the afternoon clinic, in spite of the comparatively high doses of chlorpropamide. It will be seen that in Cases 2, 3, and 9 the same daily dosage of chlorpropamide was given throughout the pregnancy and all three babies survived, though one baby (Case 2) was heavy-fordates ( $>90$ th centile). The total amounts of chlorpropamide given varied considerably, from $5 \cdot 25 \mathrm{~g}$ to $105 \mathrm{~g}$ (mean $43 \cdot 04 \pm 23.97 \mathrm{~g} \mathrm{SD}$ ), and the infant in the latter case (Case 9) survived, while in the former (Case 12) neonatal death occurred from respiratory distress syndrome (hyaline membrane disease.)

Case 4, who had an intrauterine death at 31 weeks' gestation, was a 37-year-old multipara who had had a previous stillbirth and whose fasting blood sugar was $160 \mathrm{mg} / 100 \mathrm{ml}$ at 30 weeks, having had a postprandial level of $197 \mathrm{mg} / 100 \mathrm{ml}$ the previous week when the chlorpropamide dosage was doubled to $500 \mathrm{mg}$ /day. There were no additional obstetric features compromising fetal survival.

Case 11 was a multipara, aged 40 , who had had a previous neonatal death, and required increasing doses of chlorpropamide to control the blood sugar from the 26th week when the level was found to be $186 \mathrm{mg} / 100 \mathrm{ml}$, but intrauterine death occurred at 34 weeks' gestation, and there were no additional pathological obstetric features to which fetal death could be attributed.

One infant (of Case 12) died in the neonatal period. The mother had had a previous intrauterine death thought to be the result of poor placental function. The baby, a breech presentation, was delivered by a lower uterine segment caesarean section and weighed $3630 \mathrm{~kg}$ at birth. The mother was unsure of the date of the last menstrual period. Though spontaneous respiration occurred at $1 \frac{1}{2}$ minutes, and the Apgar score at 1 and 5 minutes was 7 and 8 , respectively, the baby, who had the typical appearance of an infant of a diabetic mother, started to grunt almost immediately and was nursed in an incubator with humidified oxygen. Increasing respiratory distress and cyanosis developed, her condition deteriorated, and despite intubation, artificial ventilation, and correction of metabolic acidosis, she died at the age of 27 hours. Necropsy revealed pulmonary hyaline membrane disease, pancreatic islet cell hyperplasia, and haemorrhage into the renal medullary pyramids.

Table I shows the mean levels of whole blood glucose and plasma insulin in the maternal vein and in the cord artery and vein which were taken simultaneously at birth in 3 of the chlorpropamidetreated group, and also shows the mean of these compared with the mean values obtained from a series of 9 untreated pregnancies in which glucose intolerance was less marked. There was no evidence of maternal hypoglycaemia or hyperinsulinism, or of fetal hypoglycaemia in either group. There were higher cord arterial and venous plasma insulin levels in the babies of the chlorpropamidetreated group compared with the mean of the untreated group, and this was most apparent in Case 14. It is of interest to note that this woman received only $8.4 \mathrm{~g}$ chlorpropamide during pregnancy and her insulin level was low at delivery though her blood sugar was high. We interpret not only the remarkably high cord insulin levels as a reflection of this poor control, but also the high birthweight centile ( $>90$ th) of the baby. 
TABLE I

Blood glucose and plasma insulin levels at delivery in untreated chemical diabetics and in 3 chlorpropamidetreated diabetics

\begin{tabular}{|c|c|c|c|c|c|c|}
\hline \multirow{2}{*}{ Antenatal treatment } & \multicolumn{2}{|c|}{ Maternal vein } & \multicolumn{2}{|c|}{ Cord vein } & \multicolumn{2}{|c|}{ Cord artery } \\
\hline & $\begin{array}{c}\text { Glucose } \\
(\mathrm{mg} / 100 \mathrm{ml})\end{array}$ & Insulin $(\mu \mathrm{U} / \mathrm{ml})$ & $\begin{array}{c}\text { Glucose } \\
(\mathrm{mg} / 100 \mathrm{ml})\end{array}$ & Insulin $(\mu \mathrm{U} / \mathrm{ml})$ & $\begin{array}{c}\text { Glucose } \\
(\mathrm{mg} / 100 \mathrm{ml})\end{array}$ & Insulin $(\mu \mathrm{U} / \mathrm{ml})$ \\
\hline $\begin{array}{l}\text { Chlorpropamide } \\
\text { Case } 8(40.6 \mathrm{~g}) \\
13(16.6 \mathrm{~g}) \\
14(8.4 \mathrm{~g}) \\
\text { Mean } \\
\text { No treatment } \\
\text { Mean } \pm \text { SD of } 9 \text { cases }\end{array}$ & $\begin{array}{c}128 \\
112 \\
152 \\
130 \cdot 7 \\
131 \cdot 9 \pm 51 \cdot 3\end{array}$ & $\begin{array}{c}42 \\
20 \\
13 \\
25 \cdot 0 \\
31 \cdot 9 \pm 15 \cdot 3\end{array}$ & $\begin{array}{c}110 \\
103 \\
97 \\
103 \cdot 3 \\
110 \cdot 4 \pm 38 \cdot 6\end{array}$ & $\begin{array}{c}98 \\
35 \\
500 \\
211 \cdot 0 \\
21 \cdot 2 \pm 10 \cdot 6\end{array}$ & $\begin{array}{c}108 \\
77 \\
70 \\
85 \cdot 0 \\
93 \cdot 1 \pm 39 \cdot 9\end{array}$ & $\begin{array}{c}83 \\
30 \\
500 \\
204 \cdot 3 \\
17 \cdot 1 \pm 5 \cdot 0\end{array}$ \\
\hline
\end{tabular}

In Fig. 2 (and Table II) the neonatal capillary whole blood glucose levels are plotted from birth for the first $\mathbf{9 0}$ minutes of life at $\mathbf{3 0}$ minute intervals in the two groups. The lower mean blood glucose levels in the infants of the chlorpropamide-treated mothers appear to derive from a lower initial blood glucose level and a faster rate of fall in the first 30 minutes of life, but thereafter there appears to be no difference in the rate of decline compared to the group of infants of untreated mothers. Despite the high fetal insulin values in Case 14, the capillary blood glucose fell from 87 to $40 \mathrm{mg} / 100 \mathrm{ml}$ in the first 90 minutes of life. Unfortunately, these small numbers do not justify statistical analysis.

Fig. 3 (and Table III) shows the fasting plasma insulin levels and the insulin response to the intravenous glucose, with the mean rates of glucose

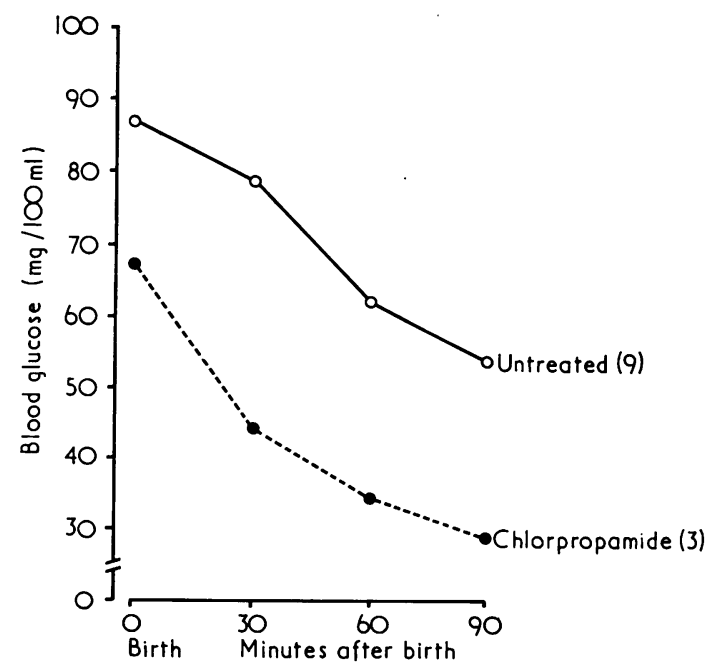

Fig. 2.-Capillary blood glucose levels in the first 90 minutes after birth in the two groups studied.
TABLE II

Capillary blood glucose levels from birth to 90 minutes of life (relating to the values in Fig. 2)

\begin{tabular}{c|c|c|c|c}
\hline \multirow{2}{*}{$\begin{array}{c}\text { Time } \\
\text { (min after } \\
\text { birth) }\end{array}$} & \multicolumn{2}{|c|}{ Chlorpropamide (3) } & \multicolumn{2}{|c}{ Untreated (9) } \\
\cline { 2 - 4 } & Mean & Range & Mean \pm SD & Range \\
\hline 0 & $66 \cdot 7$ & $50-87$ & $86 \cdot 7 \pm 31 \cdot 7$ & $53-132$ \\
30 & $44 \cdot 0$ & $27-63$ & $78 \cdot 6 \pm 25 \cdot 9$ & $43-124$ \\
60 & $34 \cdot 0$ & $23-50$ & $62 \cdot 3 \pm 25 \cdot 3$ & $17-106$ \\
90 & $29 \cdot 3$ & $23-40$ & $54 \cdot 2 \pm 24 \cdot 0$ & $13-92$ \\
\hline
\end{tabular}

disposal expressed as increment indices (II) and as $K$ values (also in Table III) completed within the first 4 hours after birth in the two groups. The peak insulin response is earlier in the chlorpro-

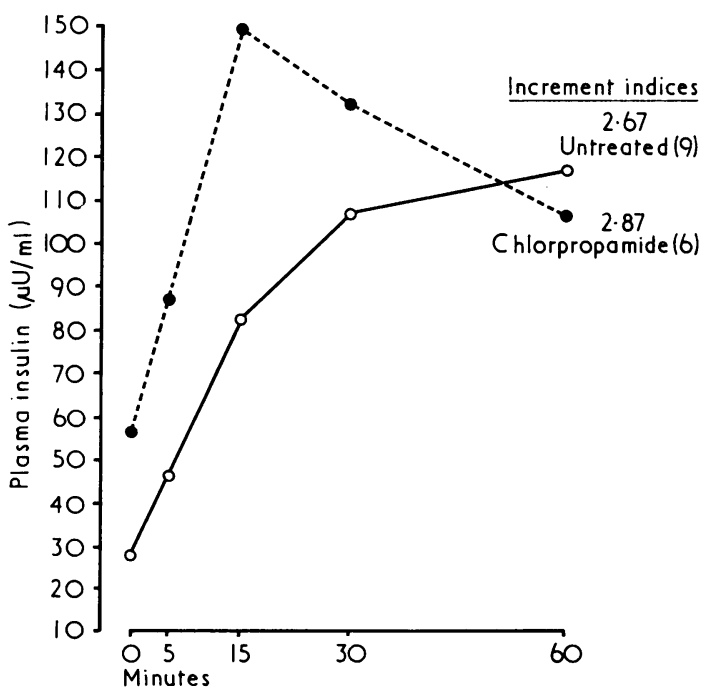

Fig. 3.-Plasma insulin and increment indices of an intravenous glucose tolerance test in infants of untreated chemical diabetics and in chlorpropamide-treated diabetic mothers. 
TABLE III

Plasma insulin, increment indices (II), and $K$ values of intravenous glucose tolerance tests in infants of untreated chemical diabetics and in chlorpropamide-treated mothers (relating to the values in Fig. 3)

\begin{tabular}{|c|c|c|c|c|}
\hline & \multicolumn{4}{|c|}{ Insulin levels $(\mu \mathrm{U} / \mathrm{ml})$} \\
\hline & \multicolumn{2}{|c|}{ Chlorpropamide (6) } & \multicolumn{2}{|c|}{ Untreated (9) } \\
\hline & Mean \pm SD & Range & Mean $\pm S D$ & Range \\
\hline $\begin{array}{l}\text { Fasting } \\
5 \mathrm{~min} \\
15 \mathrm{~min} \\
30 \mathrm{~min} \\
60 \mathrm{~min} \\
\mathrm{II} \\
\mathrm{K} \text { value }\end{array}$ & $\begin{array}{c}56 \cdot 3 \pm 62 \cdot 2 \\
88 \cdot 2 \pm 64 \cdot 6 \\
150 \cdot 8 \pm 119 \cdot 3 \\
133 \cdot 0 \pm 141 \cdot 2 \\
107 \cdot 7 \pm 92 \cdot 2 \\
2 \cdot 87 \pm 1 \cdot 76 \\
1 \cdot 89 \pm 1 \cdot 25\end{array}$ & $\begin{array}{c}16-180 \\
78-200 \\
120-350 \\
36-350 \\
62-152 \\
1 \cdot 69-6 \cdot 3 \\
1 \cdot 08-4 \cdot 33\end{array}$ & $\begin{array}{r}29 \cdot 0 \pm 14 \cdot 6 \\
47 \cdot 1 \pm 25 \cdot 3 \\
83 \cdot 3 \pm 48 \cdot 4 \\
108 \cdot 3 \pm 87 \cdot 8 \\
116 \cdot 9 \pm 85 \cdot 1 \\
2 \cdot 67 \pm 0 \cdot 75 \\
1 \cdot 48 \pm 0 \cdot 42\end{array}$ & $\begin{array}{c}11-51 \\
18-88 \\
24-174 \\
42-328 \\
40-300 \\
1 \cdot 44-3 \cdot 65 \\
0 \cdot 98-2 \cdot 24\end{array}$ \\
\hline
\end{tabular}

pamide-treated group and it is possible that the peak in the infants of the untreated group occurred later than 60 minutes, at which time the insulin values in the two groups are similar. In spite of the more brisk and greater insulin response in the chlorpropamide-treated group, the rate of glucose disposal was not significantly greater than in the infants of the untreated mothers.

Clinical and biochemical details of the infants are presented in Table IV. There were no serious congenital abnormalities in the group. There was no correlation between fetal distress in labour and subsequent asphyxia, clinical appearance, or clinical and biochemical signs. All 5 infants with infection had omphalitis, and in addition Case 5 had cutaneous moniliasis. The high incidence of omphalitis may be related to the use of the umbilical vein for early intravenous dextrose feeding; omphalitis occurred in only one case (Case 9) who had an intravenous glucose tolerance test. In no case was the omphalitis severe.

The relation between total maternal chlorpropamide dosage, control of maternal diabetes, and condition of the newborn is presented in Table V. It is apparent that when diabetic control during pregnancy was good the condition of the infant was similar whether the total dose of chlorpropamide was high or low, and when diabetic control was bad the condition of the infants in both high and low dosage groups was worse than in either of the two groups with good maternal control. All infants from badly controlled pregnancies showed clinical or biochemical abnormalities, whereas half the infants from well-controlled pregnancies showed no clinical or biochemical abnormalities other than typical appearance'.

\section{Discussion}

Jackson et al. (1962) reported a series of 40 pregnancies in diabetic women treated with sulphonylureas. Chlorpropamide was used in 20 pregnancies in a dose of $500 \mathrm{mg}$ and in 3 pregnancies in a dose of $250 \mathrm{mg}$ daily. All were overt diabetics and control of the metabolic state was described as good, though the standards of control were admitted to be wide. There were 14 perinatal deaths, all occurring in pregnancies in which $500 \mathrm{mg}$ daily had been used. No congenital malformations were recorded even where the higher dose had been used. In an addendum the outcome of 2 further pregnancies was recorded, in both of which the mother had received $500 \mathrm{mg}$ daily. One infant was stillborn and one died at 18 hours, but neither showed any congenital abnormality.

Subsequently Campbell (1963), one of the co-authors of the above paper, related that one of the survivors of this series presented at 10 months with microcephaly and quadriplegia.

Sterne and Lavieuville (1963) conducted a postal survey in France and obtained information about only 2 pregnancies in which chlorpropamide was given, both of which had a successful outcome.

In 1964, Malins et al. reported an analysis of the outcome of the pregnancies in 41 women who received oral hypoglycaemic agents. The cases were divided into 23 who received the drugs in the first and second trimesters only (and who presumably received insulin subsequently until delivery) and 18 who received them in the last trimester only. In the first group 22 were overt diabetics. 15 of the 23 received chlorpropamide and the single fatality was a stillbirth in a woman who received $375 \mathrm{mg}$ chlorpropamide daily. In the second group, 5 women were overt diabetics and 13 were 'latent' diabetics. 11 of the 18 received chlorpropamide and two stillbirths and one neonatal death resulted. The stillbirths occurred in the women receiving $500 \mathrm{mg}$ and $250 \mathrm{mg}$ daily, and 
Details of chinic

\begin{tabular}{|c|c|c|c|c|c|c|c|}
\hline Case no. ${ }^{\star}$ & $\begin{array}{l}\text { Clinical fetal } \\
\text { distress }\end{array}$ & $\begin{array}{l}\text { Placental weight } \\
\text { (g) }\end{array}$ & $\begin{array}{c}\text { Intubation at } \\
\text { birth }\end{array}$ & $\begin{array}{c}\text { Apgar score } \\
(1 / 5 \mathrm{~min})\end{array}$ & $\begin{array}{c}\text { Clinical } \\
\text { appearance }\end{array}$ & $\begin{array}{l}\text { Respiratory } \\
\text { distress }\end{array}$ & 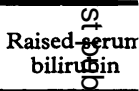 \\
\hline 1 & - & 850 & + & $3 / 8$ & + & + & $\overline{\bar{\omega}}$ \\
\hline 2 & - & 525 & - & $5 / 10$ & - & - & จे \\
\hline 3 & - & 770 & - & $9 / 9$ & - & + & $\varrho$ \\
\hline 4 & - & 850 & & & & & פ) \\
\hline 5 & - & 375 & - & 9/9 & - & _- & $\omega$ \\
\hline 6 & + & 500 & - & $9 / 10$ & + & - & $\overrightarrow{\overrightarrow{0}}$ \\
\hline 7 & - & 260 & + & $1 / 9$ & - & - & 0 \\
\hline 8 & - & 650 & - & $8 / 10$ & - & - & $\vec{z}$ \\
\hline 9 & - & 540 & - & $9 / 10$ & - & - & $\vec{\omega}$ \\
\hline 10 & - & 500 & _ & $9 / 10$ & + & - & ఠ) \\
\hline 11 & - & 510 & & & & & ญి \\
\hline 12 & - & 992 & - & $7 / 8$ & + & + & 응 \\
\hline 13 & + & 550 & - & $7 / 10$ & - & - & 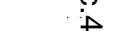 \\
\hline 14 & - & 600 & + & $5 / 7$ & + & - & 艹 \\
\hline 15 & + & 350 & - & $2 / 10$ & - & - & is \\
\hline 16 & - & 775 & - & $8 / 9$ & + & - & $+\dot{\sim}$ \\
\hline 17 & - & 650 & + & $1 / 6$ & + & - & మ్ర \\
\hline 18 & - & 500 & - & $9 / 9$ & - & - & $\omega$ \\
\hline 19 & - & 510 & - & $8 / 9$ & - & - & 옥 \\
\hline
\end{tabular}

^Identical to mother's in Fig. 1.

Note: Raised serum bilirubin, hypoglycaemia, and hypocalcaemia are defined in the text. + , present; -, absent; IUD, intrauterine ${ }_{d e a t}$

TÂेL

Relation between control of maternal diabetes fot,

\begin{tabular}{|c|c|c|c|c|c|}
\hline \multirow{3}{*}{$\begin{array}{c}\text { Total } \\
\text { chlorpropamide } \\
\text { dosage category }\end{array}$} & \multicolumn{5}{|c|}{ Good } \\
\hline & \multirow[b]{2}{*}{ Case no. } & \multirow{2}{*}{$\begin{array}{l}\text { Total amount of } \\
\text { chlorpropamide } \\
\text { (g) }\end{array}$} & \multicolumn{3}{|c|}{ Infant } \\
\hline & & & $\begin{array}{c}\text { Clinical } \\
\text { appearance }\end{array}$ & $\begin{array}{c}\text { Clinical } \\
\text { signs }\end{array}$ & $\begin{array}{l}\text { Biochergîn } \\
\text { abnormality }\end{array}$ \\
\hline $\begin{array}{c}\text { Low } \\
(<43.04 \mathrm{~g})\end{array}$ & $\begin{array}{r}5 \\
7 \\
8 \\
10 \\
13 \\
15\end{array}$ & $\begin{array}{l}21 \cdot 70 \\
42 \cdot 0 \\
40 \cdot 60 \\
26 \cdot 60 \\
16 \cdot 60 \\
23 \cdot 80\end{array}$ & $\begin{array}{l}- \\
- \\
- \\
+ \\
- \\
-\end{array}$ & $\begin{array}{l}+ \\
+ \\
- \\
- \\
- \\
+\end{array}$ & $\begin{array}{l}+\frac{0}{10} \\
-00 \\
-00 \\
-\frac{0}{2} \\
-\frac{0}{3}\end{array}$ \\
\hline Mean & & $28 \cdot 55$ & & & ฉి \\
\hline$\underset{(>43.04 \mathrm{~g})}{\text { High }}$ & $\begin{array}{r}2 \\
3 \\
6 \\
9 \\
18 \\
19\end{array}$ & $\begin{array}{c}68 \cdot 25 \\
54 \cdot 60 \\
44 \cdot 80 \\
105 \cdot 0 \\
67 \cdot 20 \\
57 \cdot 75\end{array}$ & $\begin{array}{l}- \\
- \\
+ \\
- \\
-\end{array}$ & $\begin{array}{l}- \\
+ \\
- \\
- \\
+ \\
-\end{array}$ & $\begin{array}{l}+0 \\
+0 \\
-2 \\
+\frac{1}{0} \\
+0\end{array}$ \\
\hline Mean & & $66 \cdot 26$ & & & 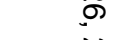 \\
\hline
\end{tabular}

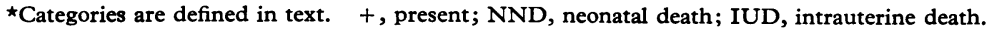

neonatal death in the infant of a woman taking 100 $\mathrm{mg}$ daily for an unstated duration of her pregnancy.

Moss and Connor (1965) reported the use of chlorpropamide in two mild diabetics who were both obese and diagnosed 12 months previously. In one, $500 \mathrm{mg}$ was given daily from the 28 th week of gestation until delivery at $\mathbf{4 3}$ weeks of a stillbirth (weight $4649 \mathrm{~g}$ ). In the other, a dose of $500 \mathrm{mg}$ daily was given for 13 weeks in the second and third trimesters. Therapy was then changed to insulin for 4 weeks before delivery at 36 weeks and a healthy infant weighing $3799 \mathrm{~g}$ was born.

Douglas and Richards (1967) in Jamaica reported on 34 pregnant women over the age of 30 who received chlorpropamide during pregnancy; 5 were taking it at conception, 19 began between the 14th 
searance of infants

\begin{tabular}{|c|c|c|c|c|c|c|}
\hline Jitteriness & $\begin{array}{c}\text { Cyanotic/apnoeic } \\
\text { attack }\end{array}$ & Hypoglycaemia & Hypocalcaemia & $\begin{array}{l}\text { Congenital } \\
\text { abnormality }\end{array}$ & Infection & $\begin{array}{l}\text { Intravenous fluids } \\
\text { (umbilical vein) }\end{array}$ \\
\hline - & + & + & - & - & - & + \\
\hline- & - & + & + & - & + & + \\
\hline - & - & - & + & - & - & - \\
\hline 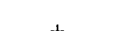 & IUD & & & & & \\
\hline \pm & - & $\overline{-}$ & + & $\overline{-}$ & \pm & $=$ \\
\hline+ & - & + & + & - & + & + \\
\hline- & - & - & - & - & - & - \\
\hline- & - & - & - & - & + & - \\
\hline- & - & - & - & PWS & - & - \\
\hline- & IUD & & & & & \\
\hline$\overline{-}$ & \pm & - & $\overline{-}$ & $\overline{-}$ & - & + \\
\hline- & - & - & + & - & I & 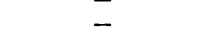 \\
\hline+ & - & - & - & - & - & - \\
\hline+ & + & - & - & - & + & + \\
\hline+ & + & + & + & - & - & + \\
\hline- & + & - & + & - & - & - \\
\hline- & - & - & - & - & - & - \\
\hline
\end{tabular}

S, port wine stain.

orpropamide dosage category, ${ }^{\star}$ and condition of infant

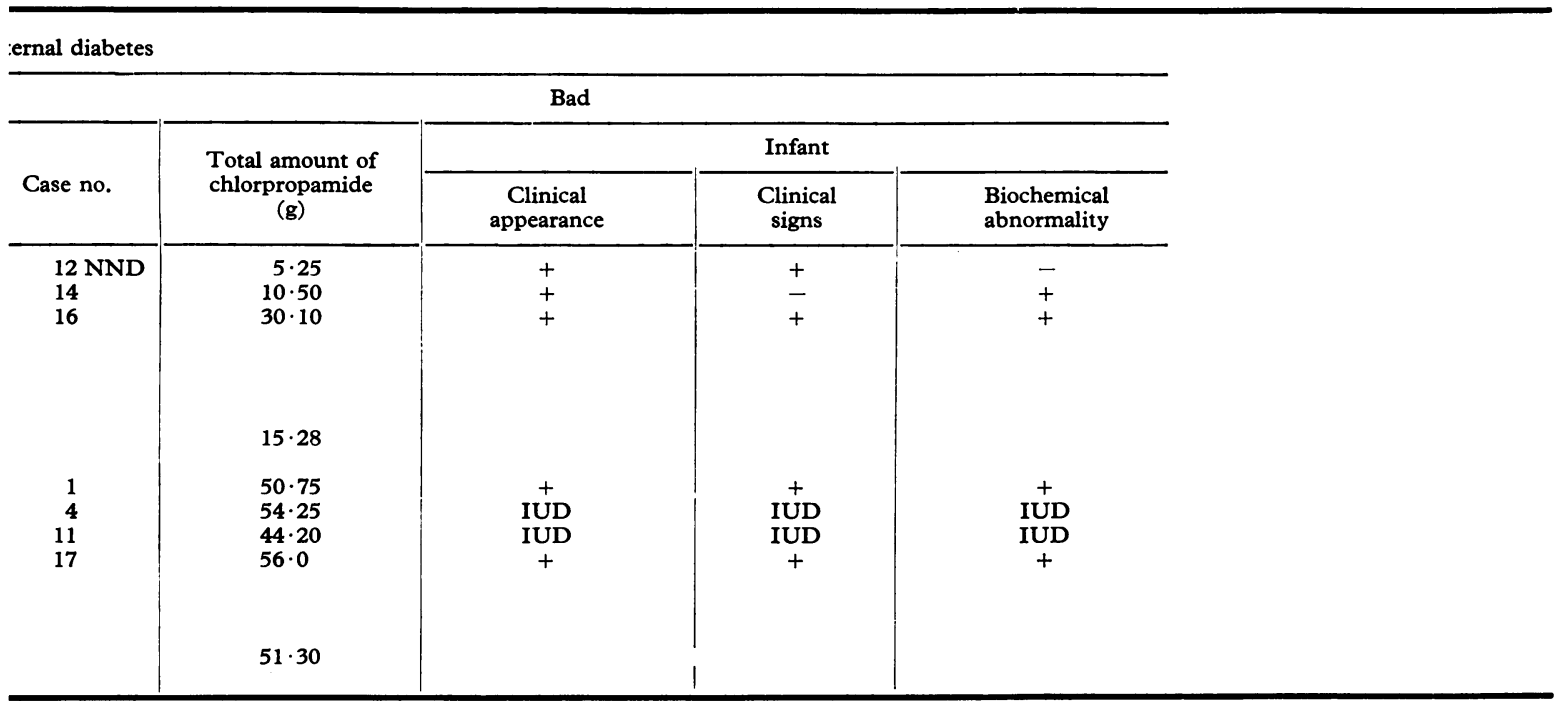

and 27 th week, and 19 began at the 28th week or later. The fetus died in 4 cases.

Notelovitz (1971), a co-author in the paper of Jackson et al. (1962), gave a reappraisal of that work and reported the results of a prospective study of 207 pregnant diabetics. Those already on treatment continued with it but others were randomly allocated to groups treated with chlorpropamide, tolbutamide, insulin, and diet alone. 7 of the original 65 receiving chlorpropamide were subsequently changed to insulin for better control. Of the 58 continuing with chlorpropamide (to a maximum of $250 \mathrm{mg}$ daily), $80 \%$ were well controlled (postprandial blood sugar level $<150$ $\mathrm{mg} / 100 \mathrm{ml}), 12 \cdot 5 \%$ had fair control (150-200 $\mathrm{mg} / 100 \mathrm{ml}$ ), and $7 \cdot 5 \%$ were controlled only poorly 
$(>200 \mathrm{mg} / 100 \mathrm{ml})$. There were 7 stillbirths in the group and 1 neonatal death, the latter occurring after an erroneous premature induction of labour at 35 weeks. 4 of the stillbirths were attributed to obstetric factors, 1 to poor diabetic control, and 2 were of undetermined cause. There were two instances of congenital malformation in the whole series but in neither case did the woman receive chlorpropamide.

From the information available in the reports quoted it appears that there is no increased incidence of congenital malformations in the infants of mothers who have received chlorpropamide during pregnancy even in doses of up to $500 \mathrm{mg}$ daily. The reports strengthen the impression gained from our own experience of an association between the incidence of stillbirths and the use of chlorpropamide in pregnancy particularly when higher doses are used, but it is impossible to determine from these reports whether this is because chlorpropamide is harmful to the fetus in late pregnancy or because the diabetic state of the mother is inadequately controlled.

There is an increased risk of neurological damage (Anderson, Milner, and Strich, 1966) occurring in infants with neonatal hypoglycaemia. Many consider that the onset of symptoms should be forestalled rather than awaited, with early carbohydrate feeding (Brown and Wallis, 1963; Haworth et al., 1963).

Neonatal hypoglycaemia may be associated with either reduced or excessive amounts of liver glycogen, as is seen in small-for-dates infants and in heavy-for-dates infants of insulin-dependent diabetic mothers. Intrauterine malnutrition has been adduced as a cause for neonatal hypoglycaemia, resulting in clinical abnormalities and requiring treatment (Neligan, Robson, and Watson, 1963). There are several reports of prolonged symptomatic hypoglycaemia in infants of mothers who have received chlorpropamide. Kemball et al. (1970) collected 4 neonates with prolonged symptomatic hypoglycaemia and suggested that chlorpropamide, having crossed the placenta in utero, persisted in the infant circulation possibly with a prolonged half-life and by stimulation of infant islet tissue caused persistent hypoglycaemia. Only 2 of these mothers had had more than $100 \mathrm{mg}$ chlorpropamide daily.

Zucker and Simon (1968) reported a case in which the mother had received $500 \mathrm{mg}$ chlorpropamide daily throughout pregnancy. The infant was hypoglycaemic and had a chlorpropamide level of $15.4 \mathrm{mg} / 100 \mathrm{ml}$ at 77 hours, falling to $6.4 \mathrm{mg} / 100$ $\mathrm{ml}$ before an exchange transfusion at 108 hours. The infant did well subsequently and was said to be normal at one year. However, none of the infants in the study by Kemball et al. (1970) had chlorpropamide values above $3.0 \mathrm{mg} / 100 \mathrm{ml}$. The therapeutic range in adults appears (Handelsman, Levitt, and Calabretta, 1959) to lie between 3.0 and $14.0 \mathrm{mg} / 100 \mathrm{ml}$. It is not known if the fetal pancreas is as sensitive to chlorpropamide as the adult pancreas.

When the mother has received chlorpropamide up to the time of delivery the interpretation of the cause of the neonatal hypoglycaemia is even more complex. It may be that chlorpropamide, in a dose regimen adequate to control maternal and fetal blood sugar levels and to prevent fetal islet stimulation through the agency of glucose, is in a sufficiently high concentration to be a potent pharmacological $\beta$-cytotrophic stimulus to the fetal pancreas. Resolution of this dilemma is complicated by the fact that higher doses of the drug are required for the control of the most severe diabetics whose babies are at greater risk. However, Case 9 of Fig. 1 and Table IV illustrates the fact that large doses of chlorpropamide can be given up to delivery without inducing hypoglycaemia in the infant. So far as it was possible on a clinical rating to assess the relative effects of the two potential stimuli of fetal hyperinsulinism in this series (Table V), chlorpropamide appeared to have the lesser effect, because it seems from this study that the infant's condition is more closely related to the control of maternal diabetes than to the total dosage of chlorpropamide taken during pregnancy.

Whereas the data in this paper can be interpreted to indicate that it is justifiable to use large doses of chlorpropamide in pregnancy because satisfactory results were obtained for the fetus when the maternal diabetes was well controlled, we do not in fact recommend this because the range of efficacy of the chlorpropamide is limited and the facilities for day-to-day adjustment of blood sugar are less good than with the use of insulin. Over the last 2 years chlorpropamide has been used in a dose not exceeding $100 \mathrm{mg}$ for mild diabetes in pregnancy, and in every case studied the maternal diabetes has been reversed and the babies have done well (Sutherland et al., 1973). More severe cases of diabetes have been treated with insulin in preference to higher doses of chlorpropamide.

We thank the British Diabetic Association for part-time support of H.W.S. and the clerical help provided by Mrs. Kathleen Anderson; the Scottish Hospitals Endowment Research Trust for support given to Mr. Raymond Christie who provided technical help; and R. O. Duncan and I. Pittendreigh for technical help.

We thank Dr. Gordon G. Hems for his statistical 
advice and Professors Ian MacGillivray and Ross G. Mitchell for their co-operation and encouragment.

\section{REFERENCES}

Anderson, J. M., Milner, R. D. G., and Strich, S. J. (1966). Pathological changes in the nervous system in severe neonatal hypoglycaemia. Lancet, $2,372$.

Brown, R. J. K., and Wallis, P. G. (1963). Hypoglycaemia in the newborn infant. Lancet, $1,1278$.

Campbell, G. D. (1963). Chlorpropamide and foetal damage. British Medical fournal, 1, 59.

Douglas, C. P., and Richards, R. (1967). Use of chlorpropamide in the treatment of diabetes in pregnancy. Diabetes, 16, 60.

Duncan, L. J. P. (1956). The intravenous glucose tolerance test. Quarterly fournal of Experimental Physiology, 41, 85.

Hales, C. N., and Randle, P. J. (1963). Immunoassay of insulin with insulin-antibody precipitate. Biochemical fournal, 88, 137.

Handelsman, M. B., Levitt, L., and Calabretta, M. F. (1959). A laboratory and clinical study of chlorpropamide in ambulatory diabetics. Annals of the New York Academy of Sciences, 74, 632.

Haworth, J. C., Coodin, F. J., Finkel, K. C., and Weidman, M. L. (1963). Hypoglycemia associated with symptoms in the newborn period. Canadian Medical Association fournal, 88, 23.

Hugget, A. St. G., and Nixon, D. A. (1957). Use of glucose oxidase, peroxidase, and $\mathrm{O}$-dianisidine in determination of blood and urinary glucose. Lancet, 2,368 .

Hytten, F. E., and Leitch, I. (1971). The Physiology of Human Pregnancy, 2nd ed., p. 279. Blackwell Scientific Publications, Oxford.

Jackson, W. P. U., Campbell, G. D., Notelovitz, M., and Blumsohn, D. (1962). Tolbutamide and chlorpropamide during pregnancy in human diabetics. Diabetes, 11, (Suppl.), 98.

Kemball, M. L., McIver, C., Milner, R. D. G., Nourse, C. H., Schiff, D., and Tiernan, J. R. (1970). Neonatal hypoglycaemia in infants of diabetic mothers given sulphonylurea drugs in pregnancy. Archives of Disease in Childhood, 45, 696.

Macphail, I. (1963). Chlorpropamide and foetal damage. British Medical fournal, 1, 192.

Malins, J. M., Cooke, A. M., Pyke, D. A., and Fitzgerald, M. G. (1964). Sulphonylurea drugs in pregnancy. British Medical fournal, $2,187$.

Moss, J. M., and Connor, E. J. (1965). Pregnancy complicated by diabetes. Report of 102 pregnancies including eleven treated with oral hypoglycemic drugs. Medical Annals of the District of Columbia, 34, 253.

Neligan, G. A., Robson, E., and Watson, J. (1963). Hypoglycaemia in the newborn. A sequel of intrauterine malnutrition. Lancet, $1,1282$.

Notelovitz, M. (1971). Sulphonylurea therapy in the treatment of the pregnant diabetic. South African Medical fournal, 45, 226.

Sterne, J., and Lavieuville, M. (1963). Clinical investigations concerning the fetal effects of oral antidiabetic drugs. Presse Médicale, 71, 1547.

Sutherland, H. W., Stowers, J. M., Cormack, J. D., and Bewsher, P. D. (1973). Evaluation of the use of chlorpropamide in chemical diabetes diagnosed during pregnancy. British Medical fournal, 3,9.

Thomson, A. M., Billewicz, W. Z., and Hytten, F. E. (1968). The assessment of fetal growth. Fournal of Obstetrics and Gynaecology of the British Commonvealth, 75, 903.

Zucker, P., and Simon, G. (1968). Prolonged symptomatic neonatal hypoglycemia associated with maternal chlorpropamide therapy. Pediatrics, 42, 824.

Correspondence to Dr. H. W. Sutherland, Department of Obstetrics and Gynaecology, Aberdeen Maternity Hospital, Foresterhill, Aberdeen AB9 2ZA. 